\title{
Comparative Proteome Analysis of Rat Brain and Coronary Microvascular Endothelial Cells
}

\author{
L. LU ${ }^{1}$, P.-Y. YANG ${ }^{1}$, Y.-CH. RUI ${ }^{1}$, H. KANG ${ }^{1}$, J. ZHANG ${ }^{1}$, J.-P. ZHANG ${ }^{2}$, \\ W.-H. FENG ${ }^{2}$ \\ ${ }^{1}$ Department of Pharmacology, School of Pharmacy, and ${ }^{2}$ Department of Biochemistry, Second \\ Military Medical University, Shanghai, China
}

Received December 5, 2005

Accepted March 16, 2006

On-line available March 23, 2006

\begin{abstract}
Summary
The endothelium of different organs displays a remarkable heterogeneity, although it presents many common functional and morphological features. However, despite our knowledge of heterogeneity among endothelial cells from different sites, the differences between brain microvascular endothelial cells (BMEC) and coronary microvascular endothelial cells (CMEC) are poorly defined. The aim of this study was to investigate whether BMEC are distinct from CMEC at the protein level. Using the proteomic approach, we comparatively analyzed the proteome of cultured BMEC and CMEC. We reproducibly separated over 2000 polypeptides by using two-dimensional electrophoresis (2-DE) at $\mathrm{pH}$ range of 3-10. Using PDQuest software to process the 2-DE gel images, forty-seven protein spots were differentially expressed in the two-endothelial cells. Of these, thirty-five proteins are highly expressed in BMEC, whereas twelve proteins are highly expressed in CMEC. Fifteen proteins in BMEC and seven proteins in CMEC were identified with high confidence by matrix-associated laser desorption ionization time-of-flight mass spectrometer (MALDI-TOF-MS). Our data suggested that BMEC and CMEC were different in several aspects including cytokine and growth-related molecules, stress-related proteins, metabolic enzymes, signal transduction proteins and others. The identification of a set of proteins preferentially expressed in BMEC and CMEC provided new data on the heterogeneity of the endothelium.
\end{abstract}

Key words

Brain $\bullet$ Endothelium $\bullet$ Proteomics $\bullet$ Heart $\bullet$ Microvasculature

\section{Introduction}

Endothelial cells are widely understood to play a crucial role in the development of vascular diseases in addition to serving a broad range of physiological functions in the cardiovascular system. A number of studies have shown that endothelial cells (EC) originating from distinct cardiovascular locations have unique expression patterns and differ both at the functional and the transcriptional level (Brouland et al. 1999, Girard et al. 1999). Using microarray analysis, Chi et al. (2003) explored EC specialization on the basis of 53 endothelial cell cultures from different locations and found tissuespecific expression patterns. Hendrickx et al. (2004) 
investigated the diversity of cardiac microvascular endothelium, aortic endothelium and endocardial endothelium, and identified sets of genes preferentially expressed in endocardial endothelium. Kallmann et al. (2002) detected 35 genes specific for brain endothelium compared with umbilical cord vascular endothelium. However, as the most easily involved organs during the occurrence of atherosclerosis, the heterogeneity of brain and heart endothelium is seldom studied.

In the brain, the endothelial layer of the bloodbrain barrier forms a tight interface between blood and neuronal tissue, with active transport systems which mediate directed transport of nutrients into the CNS or of toxic metabolites out of the CNS and create a milieu essential for the function of the underlying neuronal cells. On the other hand, in the heart, coronary microvessels play a pivotal role in determining the supply of oxygen and nutrients to the myocardium by regulating the coronary flow conductance and substance transport. Many neurohumoral mediators significantly affect coronary microvascular control in an endotheliumdependent manner (Komaru et al. 2000). The regulation of coronary microvascular permeability is an important factor for the nutrient supply and for edema formation (Chilian and Layne 1990). Analyses of microvessels are important for understanding the pathophysiology of ischemic hearts and hypertrophied hearts. Moreover, it has been increasingly recognized that microvascular abnormalities may be central to the development of endorgan damage brought about by hypertension, including ischemic heart disease and stroke, and the endothelium is a favorite early target of cardiovascular diseases such as hypertension (Thuillez and Richard 2005).

In the present study, we use the techniques of proteomics to compare the protein expression profiles between the rat brain and heart microvascular endothelial cells. Using 2-DE and MALDI-TOF-MS, we identified 15 proteins with high abundance in rat primary cultured brain endothelial cells and 7 proteins in the coronary endothelial cells.

\section{Methods}

\section{Cell cultures}

Brain microvascular endothelial cells (BMEC)

Rat brain capillary fragments were isolated and endothelial cells cultured using a modification of methods introduced by Abbott et al. (1992) and Lin and Rui (1994). Briefly, fresh rat brains were obtained from 6-week-old Wistar rats, dropped into an ice-cold Buffer A (HEPES 10 mM, $\mathrm{NaHCO}_{3} 11.9$ mM, NaCl 140 mM, KCl $10 \mathrm{mM}$, BSA $0.1 \%$ ), and the cerebellum, brain stem, choroid plexus, and the meninges were carefully removed. The cortices were rolled on dry lint to remove adherent surface cells, then chopped with a scalpel for $<1 \mathrm{~min}$ into uniform 2-3 mm pieces in Buffer A, digested in a collagenase/dispase solution $(0.1 \%$, Boehringer, Mannheim, in Ca, Mg-free HBSS, 20 units/ml DNase I was added) for $1 \mathrm{~h}$ at $37^{\circ} \mathrm{C}$ to separate microvessels from other components, and then was centrifuged in $15 \%$ Dextran $\left(4500 \times \mathrm{g}, \quad 4^{\circ} \mathrm{C}\right.$ for $\left.20 \mathrm{~min}\right)$. The pellet containing crude microvessels was further digested in a second collagenase/dispase solution for $2 \mathrm{~h}$ at $37^{\circ} \mathrm{C}$. Microvascular endothelial cell were purified by a Percoll gradient (stock solution prepared from $50 \mathrm{ml}$ Percoll plus $5.5 \mathrm{ml} 10 \times \mathrm{HBSS}+45 \mathrm{ml} \mathrm{HBSS}$, centrifuged at $25000 \times \mathrm{g}$ at $4{ }^{\circ} \mathrm{C}$ for $1 \mathrm{~h}$ ) at $1000 \mathrm{x}$ for $10 \mathrm{~min}$.

\section{Coronary microvascular endothelial cells (CMEC)}

CMEC were isolated from 6-week-old Wistar rats by collagenase digestion according to the method of Nishida et al. (1993) with slight modification. Briefly, after the rats were anesthetized and heparinized, the hearts were removed and placed in an ice-cold solution (in mmmol/1, Buffer 1): $\mathrm{NaCl} \mathrm{118,} \mathrm{KCl} 4.7, \mathrm{NaH}_{2} \mathrm{PO}_{4}$ 1.2, $\mathrm{MgSO}_{4} 1.2, \mathrm{NaHCO}_{3} 25$, and glucose 11, pH 7.4, at $37{ }^{\circ} \mathrm{C}$ (gassed with $95 \% \mathrm{O}_{2} / 5 \% \mathrm{CO}_{2}$ ), then perfused 5 min through the ascending aorta to remove blood cells. Epicardial mesothelial cells were devitalized with $70 \%$ (vol/vol) ethanol. After removal of the connective tissue, the atria, right ventricular tissue and the outer one-fourth of the left ventricular free wall and septum, the remaining heart tissue was minced finely in $0.2 \%$ collagenase (Sigma type) in buffer with added $\mathrm{CaCl}_{2}(0.25 \mathrm{mmol} / \mathrm{l})$ and incubated for $30 \mathrm{~min}$ at $37{ }^{\circ} \mathrm{C}(0.7 \mathrm{mg} / \mathrm{ml})$. Trypsin $(0.02 \%)$ was added and incubated for another $30 \mathrm{~min}$. The dissociated cells were filtered through a $100-\mu \mathrm{m}$ mesh filter and washed with Buffer 1, followed by the same buffer containing calcium and centrifugation at $150 \mathrm{xg}$ for $5 \mathrm{~min}$ to remove myocytes, and then the supernatant was further centrifuged at $1000 \mathrm{xg}$ for $10 \mathrm{~min}$ and washed. Further purification of CMEC was accomplished by sequential filtration through a series of 90-, 45-, 25- and 15- $\mu \mathrm{m}$ nylon screens.

Both cells were plated on rat-tail-collagencoated dishes and were cultured in minimal essential medium containing D-valine (to inhibit growth of non-endothelial cells, US Biological), 20 \% FBS (Gibco), 
endothelial cell growth supplement $(100 \mu \mathrm{g} / \mathrm{ml})$, heparin $(120 \mathrm{U} / \mathrm{ml})$, L-glutamine $(2 \mathrm{mM})$, sodium pyruvate $(2 \mathrm{mM})$, nonessential amino acids, vitamins, penicillin $(100 \mathrm{U} / \mathrm{ml})$, and streptomycin $(100 \mu \mathrm{g} / \mathrm{ml})$. Cultures were incubated at $37{ }^{\circ} \mathrm{C}$ in a humid atmosphere of $5 \% \mathrm{CO}_{2}$. At $48 \mathrm{~h}$ after seeding, BMEC were purified by selectively lysing the contaminating astrocytes and pericytes by antibody/complement treatment. BMEC were incubated with an antibody directed against Thy 1.1 antigen (1:500, Santa Cruz) followed by incubation with rabbit complement serum (1:10, Sigma) for another $2 \mathrm{~h}$ (Risau et al. 1990).

For the experiments, primary cultured cells were used at confluence at 7 days. Morphological and immunocytochemical analyses of cells monolayers were performed with cells grown to confluency on collagencoated coverslips and were examined with an Olympus microscope with a phase contrast. Specific marker studies were carried out as previously described. Briefly, cells were grown on collagen-coated glass coverslips, washed with Hanks balanced salt solution (HBSS), fixed in cold acetone-methanol (1:1, vol/vol) for $15 \mathrm{~min}$, washed with phosphate-buffered saline containing $0.1 \%$ bovine serum albumin and $0.01 \%$ Tween, preincubated with $10 \%$ normal goat serum for $15 \mathrm{~min}$, and incubated with the appropriate antibody for $1 \mathrm{~h}$ at room temperature. After incubation with the primary antibody, the monolayers were washed with phosphate-buffered saline containing $0.1 \%$ bovine serum albumin and $0.01 \%$ Tween, incubated with peroxidaselabeled secondary antibody for $30 \mathrm{~min}$, and mounted on slides with glycerol. Specimens were viewed in a Nikon microscope. Endothelial cells were identified by using rabbit anti-rat factor VIII related antigen (dilution 1:200). Pericytes were identified by using mouse anti-smooth muscle actin (1:400).

\section{2-DE and analysis}

When primary cultures attain confluence, cellular monolayers were washed three times in PBS, harvested and suspended at a concentration of $\sim 10^{7}$ cells $/ \mathrm{ml}$ in a sample solution containing $6 \mathrm{M}$ urea, $2 \mathrm{M}$ thiourea, $2 \%$ CHAPS, $0.5 \%$ DTT and $2 \mathrm{mM} \mathrm{PMSF}$ (all from Sigma), then centrifuged at $18000 \mathrm{rpm}$ for $15 \mathrm{~min}$ at $4{ }^{\circ} \mathrm{C}$. The electrophoretic separation of proteins was performed as previously described (Neuhoff et al. 1988). Extracts containing $500 \mu \mathrm{g}$ proteins were first separated by using non-linear gradient IPG-strips, pH 3 10 (BioRad, USA), after which proteins were separated according to their size using $10 \%$ polyacrylamide gels. Protein extracts were included in the in-gel rehydration step, which proceeded over night. The rehydration solution contains: $6 \mathrm{M}$ urea, $2 \mathrm{M}$ thiourea, $2 \%$ CHAPS, $0.5 \%$ DTT and $2 \mathrm{mM}$ PMSF, $0.5 \%$ biolyte (pH 3 10) and a trace of bromophenol blue $0.01 \%(\mathrm{w} / \mathrm{v})$. Gels were stained using silver nitrate and colloidal Coomassie Brilliant Blue (CBB) according to previous reference.

CBB-stained gels were scanned using GS-800 Calibrated Densitometer (Bio-Rad) and gel images were analyzed using PDQuest 2D-image-analysis software (Bio-Rad). For a between-gel comparison, a set of spotgeneration conditions (weakest spot, smallest spot, size of the largest spot, and a selected region of the background) were used. The total density in a gel image was used to normalize each spot volume in the gel image to minimize the effect of experimental factors on spot volume. Routine statistical analyses available within the software package were used to identify up or down expressed spots. At least three independent sets of cultures of ECs were grown to extract proteins. All samples were run on three replicate gels in the Protein Dodeca Cell (Bio-Rad). Only differences that were found to be present in all of the analyzed gel pairs were considered. Protein spots of interest were subject to MALDI-TOF-MS.

\section{Protein preparation for mass spectrometry}

The in-gel digestion was performed as described earlier (Rosenfeld et al. 1992). Protein spots were excised from the CBB-stained gel and were cut into small pieces. Pieces of gel were distained twice using $60 \mu 1200 \mathrm{mmol} / 1$ $\mathrm{NH}_{4} \mathrm{HCO}_{3} / \mathrm{ACN}(50: 50 \mathrm{v} / \mathrm{v})$, shrunk by dehydration in $60 \mu 1 \mathrm{ACN}$ twice then completely dried at $37^{\circ} \mathrm{C}$ for about $20 \mathrm{~min}$. The samples were then swollen in a digestion buffer containing $100 \mathrm{mmol} / 1 \mathrm{NH}_{4} \mathrm{HCO}_{3}$ and $12.5 \mathrm{ng} / \mu \mathrm{l}$ trypsin (sequencing grade, Roche Diagnostics, USA) at $4{ }^{\circ} \mathrm{C}$ after $30 \mathrm{~min}$ incubation, and replaced with $20 \mu \mathrm{l}$ $20 \mathrm{mmol} / \mathrm{l} \mathrm{NH}_{4} \mathrm{HCO}_{3}$ without trypsin. Samples were incubated more than $12 \mathrm{~h}$ at $37{ }^{\circ} \mathrm{C}$. Peptides were then extracted twice using $5 \% \mathrm{FA}$ in $50 \%$ CAN with sonication and concentrated to about $5 \mu \mathrm{l}$ with protection of $\mathrm{N}_{2}$.

Peptide mass fingerprint by MALDI-TOF-MS and database searching

In MALDI-TOF-MS analysis, the peptide mixtures from the tryptic digests were desalted and concentrated using $10 \mathrm{ml} \mathrm{C18}$ ZipTipse (Millipore). In brief, samples were eluted in $1 \mathrm{ml}$ of $50 \%(\mathrm{v} / \mathrm{v})$ 

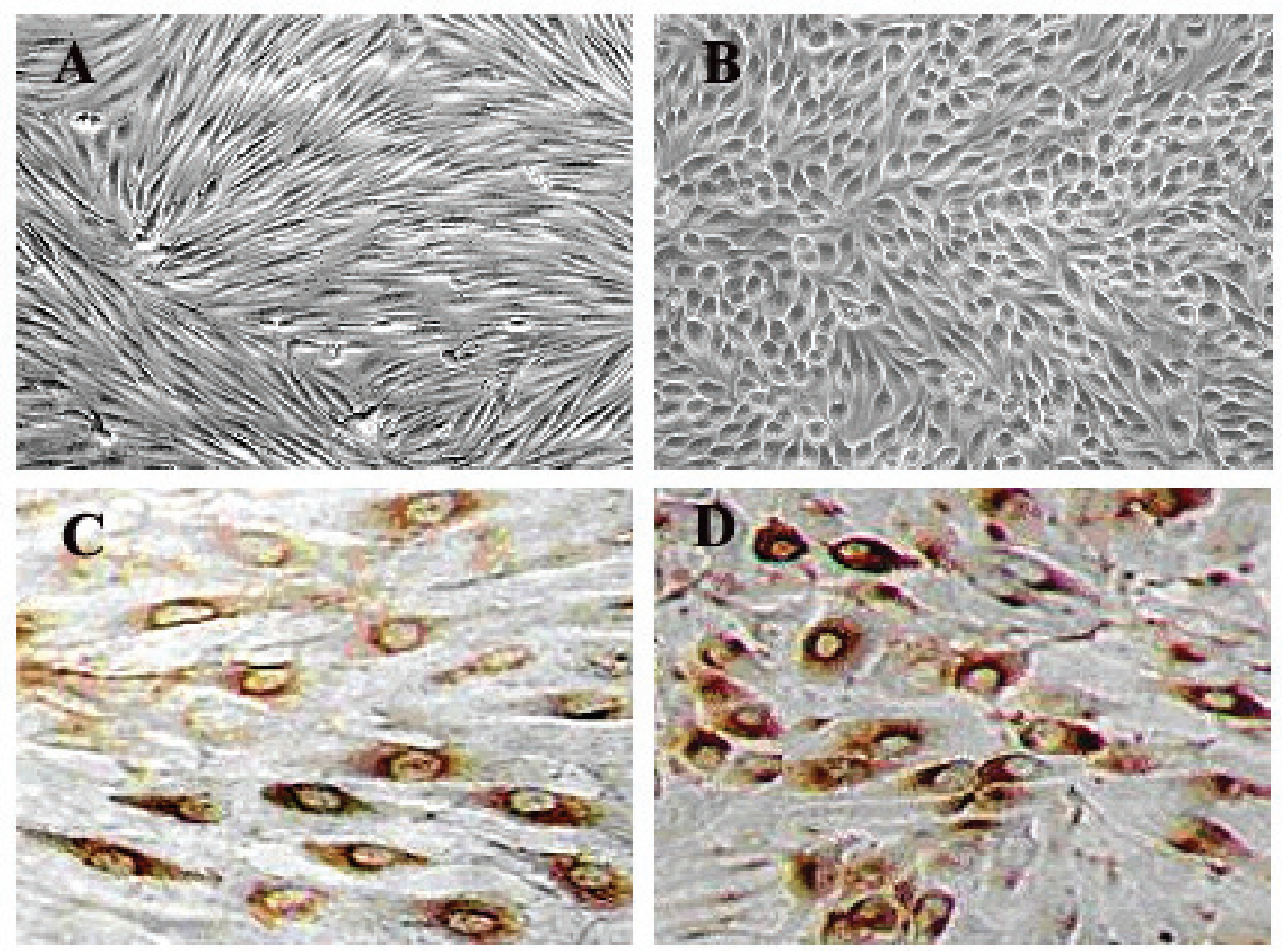

Fig. 1. Cutured rat microvascular EC. A, B, constant-phase micrograph $(\times 100)$ of a confluent monolayer of BMEC and CMEC, respectively. C, D, positive staining for the factor $\mathrm{VIII} /$ von Willebrand factor antigen $(\times 400)$ specific for BMEC and CMEC, respectively.

acetonitrile/ $0.1 \%$ trifluoroacetic acid and mixed $1: 1$ with saturated solution of $\alpha$-cyano-4-hydroxycinnamic acid in $50 \quad \% \quad(\mathrm{v} / \mathrm{v})$ acetonitrile $/ 0.3 \%$ trifluoroacetic acid. Samples were then added into a stainless steel $96 \times 2$ target MALDI plate and air-dried before analysis in the mass spectrometer. Mass spectrometry analysis was performed using a PerSeptive Biosystems Voyager DEPRO equipped with a nitrogen laser $(337 \mathrm{~nm}, 3 \mathrm{~ns}$ pulse width, $20.0 \mathrm{~Hz}$ REP Rate). Peptide mass fingerprint spectra were acquired in the reflection positive mode with accelerating voltage of $20 \mathrm{KV}$, grid voltage setting of 72 $\%$, and a 100 -ns delay using approximately 150 laser shots and calibrated using trypsin autolysis peaks as internal standards (842.5100, 2211.1046 Da). Collisionactivated dissociation (CAD) spectra in micro-HPLC-MS data and Peptide mass fingerprinting (PMF) data from MALDI-TOF-MS were analyzed by searching against an NCBInr database using MASCOT (Matrix Science, London) search software and ProteinProspector software, respectively. The Mammalia sub-database was used and one missing cleavage point of trypsin was added to the database searching.

\section{Results}

BMEC and CMEC were grown under identical culture conditions and displayed a typical cobblestone appearance and were free of contamination. The cell purity was assayed by staining with factor VIII /von Willebrand factor antibody and the anti-smooth muscle actin (Fig. 1). Samples that exhibited significant non-EC cells contamination were excluded from further analysis.

\section{Two-dimensional protein maps of BMEC and CMEC}

In this work, we established the 2-DE protein patterns of both BMEC and CMEC. More than 2000 protein spots were detected on the 2-DE gels that showed similar protein patterns with silver staining of $100 \mu \mathrm{g}$ of total proteins in both BMEC and CMEC. Figure 2 displays the overall 2-DE patterns of protein extracts of the two cell lines. Figure 3 showed a representation of the comparison of protein spots between BMEC and CMEC. More than 1200 protein spots had alkaline pIs and 759 spots fell within the acidic region with molecular masses ranging from 17 to $96 \mathrm{kDa}$. In the assessing of differential expression, we included only those proteins differentially 

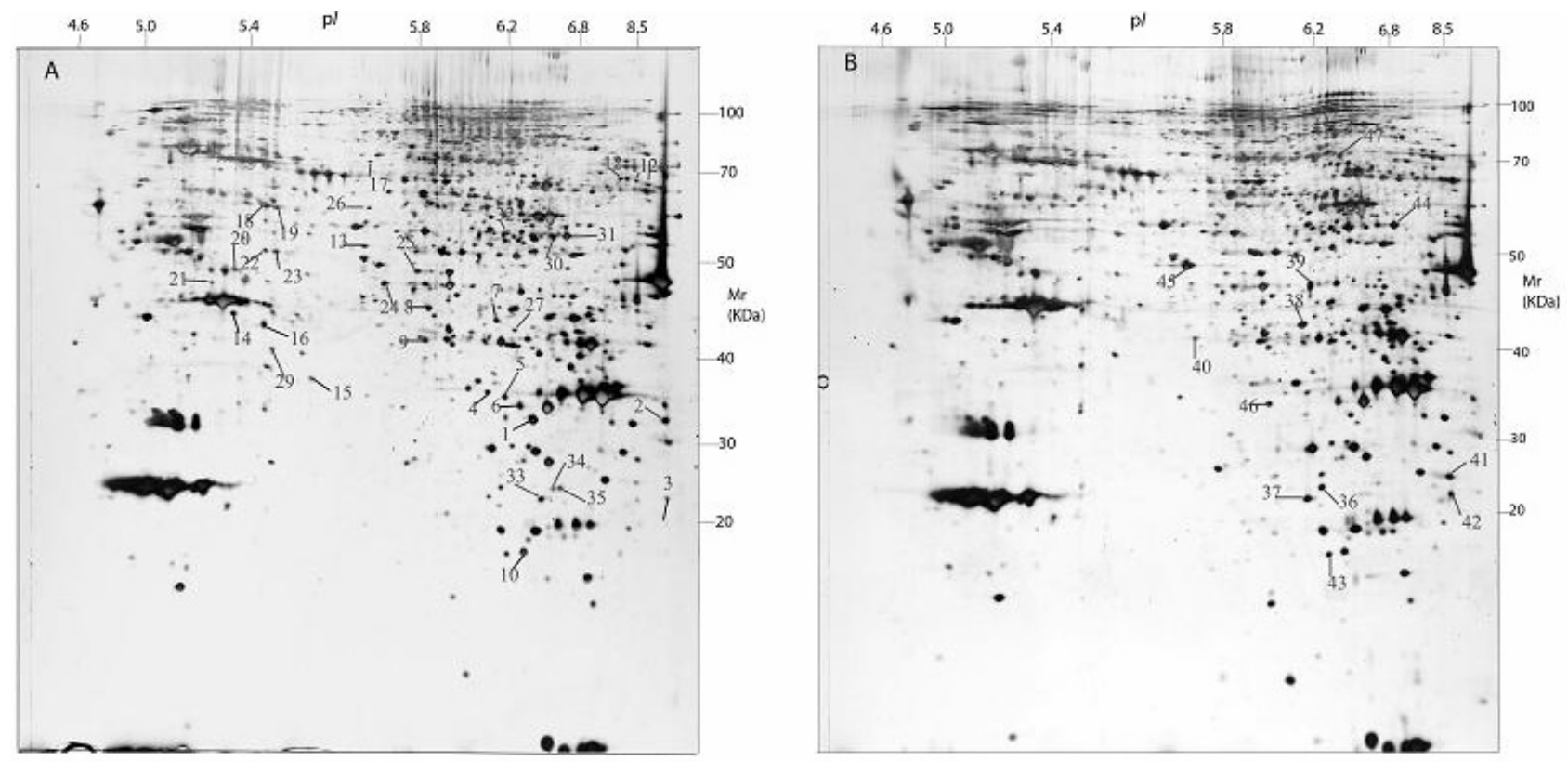

Fig. 2 . The two-dimensional protein maps of the BMEC (A) and CMEC (B). The proteins were separated using isoelectric focusing (IPG: $17 \mathrm{~cm}$, non-linearly covering a pH range of 3-10) in the first dimension, and 10\% SDS-PAGE gel in the second dimension. Gels were stained by CBB. Spots whose locations are indicated by numbers were identified and are outlined in Tables 1 and 2.

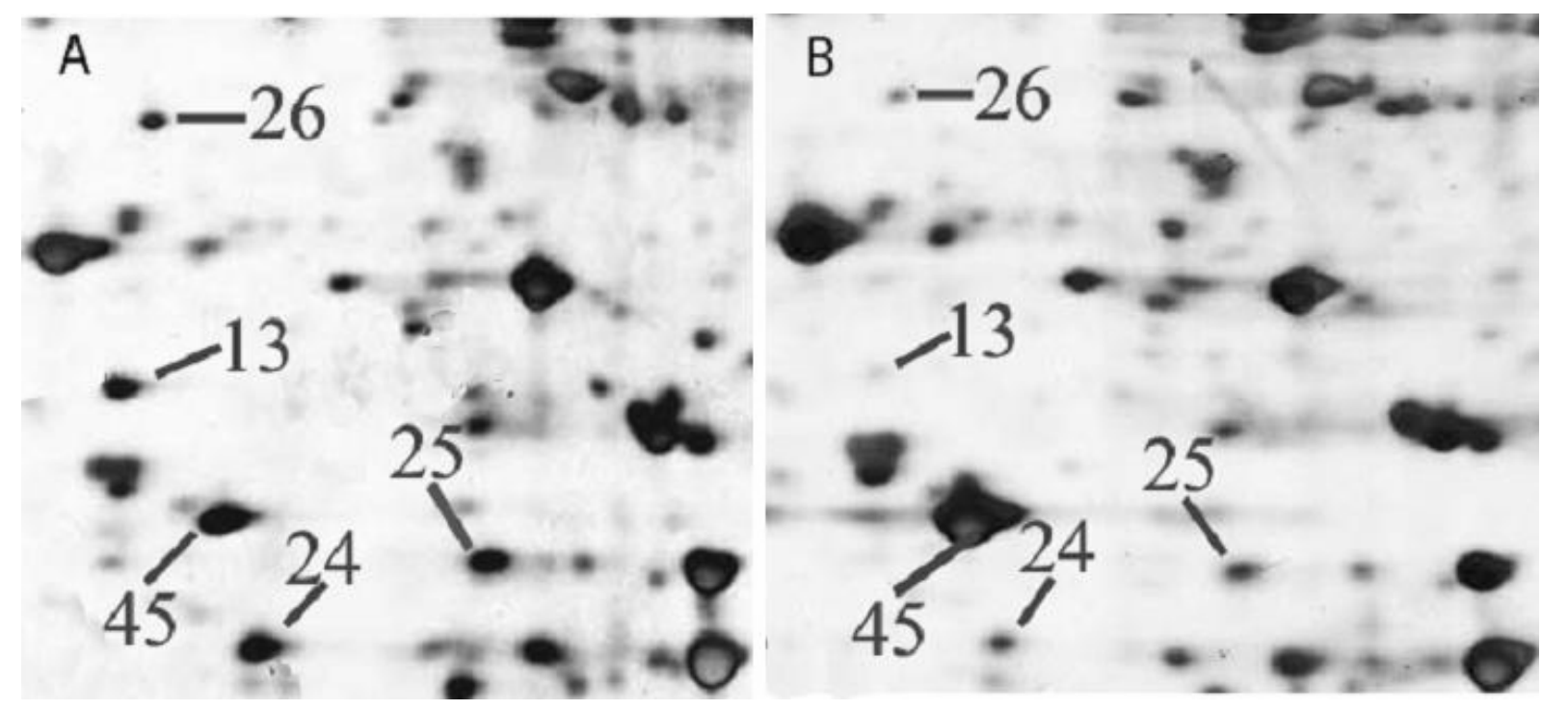

Fig. 3. Close-up of portions of the 2-DE gel images, shown in Fig. 1. The location of spots that significantly differ in BMEC (A) and CMEC (B) are indicated by numbers.

expressed consistently upon repeated analysis. Processed with PDQuest 2D-image-analysis software, 47 protein spots were differentially expressed between BMEC and CMEC. Among all the detected spots, 35 were highly expressed in BMEC and 12 were highly expressed in CMEC.

Differential protein expression profiles identified by MALDI-TOF-MS and database searching

Keeping the silver-staining gels as a reference, we excised the differentially expressed proteins from CBB stained 2-D gels and digested them with trypsin. Of these markedly changed proteins, 22 were successfully identified after MALDI-TOF-MS peptide mass fingerprinting, while 15 were up-regulated in BMEC and 7 up-regulated in CMEC. Database searches with ProteinProspector software were performed. The results had high confidence if the protein was ranked as the best hit with a significant score. The identified 15 highlyexpressed proteins in BMEC are listed in Table 1, 
Table 1. Identification of 15 proteins highly expressed by BMEC

\begin{tabular}{|c|c|c|c|c|c|c|c|}
\hline \multirow{2}{*}{ No. } & \multirow{2}{*}{ Protein name } & \multirow{2}{*}{$\begin{array}{l}\text { NCBInr } \\
\text { Index code }\end{array}$} & \multirow{2}{*}{ MW } & \multirow{2}{*}{ PI } & \multirow{2}{*}{ Score } & \multicolumn{2}{|c|}{ Spots Intensities } \\
\hline & & & & & & BMEC & CMEC \\
\hline 2 & VAMP-associated protein of $33 \mathrm{kDa}$ & gi|3320446 & 27263 & 8.27 & 143 & 1538 & 709 \\
\hline 3 & interleukin-6 & gi|6841045 & 23630 & 9.01 & 210 & 659 & 85 \\
\hline 4 & $\begin{array}{l}\text { similar to glyceraldehyde-3-phosphate } \\
\text { dehydrogenase }\end{array}$ & gi|23617935 & 31753 & 6.96 & 303 & 1453 & 156 \\
\hline 5 & macrophage capping protein & gi|729023 & 39215 & 6.73 & 203 & 5066 & 85 \\
\hline 10 & $\begin{array}{l}\text { similar to chloride intracellular channel } \\
\text { protein } 4\end{array}$ & gi|28491107 & 15989 & 6.84 & 243 & 2543 & 1297 \\
\hline 13 & selenium binding protein 2 & gi|18848341 & 52576 & 5.78 & 160 & 2487 & 67 \\
\hline 17 & $\begin{array}{l}\text { calcium/calmodulin-dependent serine protein } \\
\text { kinase membrane-associated guanylate kinase }\end{array}$ & gi|8101954 & 99120 & 6.21 & 162 & 1652 & 163 \\
\hline 20 & chaperonin subunit 8 (theta) & gi $\mid 6753328$ & 59517 & 5.44 & 141 & 677 & 55 \\
\hline 24 & caldesmon 1 & gi|21704156 & 60416 & 6.97 & 239 & 2009 & 341 \\
\hline 25 & ornithine aminotransferase & gi|8393866 & 48323 & 6.19 & 171 & 1870 & 342 \\
\hline 27 & peptidylprolyl isomerase D (cyclophilin D) & gi|13385854 & 40716 & 7.08 & 236 & 2366 & 300 \\
\hline 30 & $\begin{array}{l}\text { acetyl-coenzyme A dehydrogenase, long- } \\
\text { chain }\end{array}$ & gi|20071667 & 47877 & 8.53 & 226 & 3097 & 1890 \\
\hline 31 & similar to hypothetical protein FLJ12618 & gi|21703884 & 50866 & 8.59 & 253 & 2121 & 340 \\
\hline 32 & cytosol aminopeptidase & gi|18202835 & 52716 & 6.58 & 321 & 2433 & 1000 \\
\hline 33 & epidermal growth factor & gi|22022644 & 7514 & 12.3 & 133 & 1980 & 685 \\
\hline
\end{tabular}

Table 2. Identification of 7 proteins highly expressed by CMEC

\begin{tabular}{|c|c|c|c|c|c|c|c|}
\hline \multirow[t]{2}{*}{ No. } & \multirow[t]{2}{*}{ Protein name } & \multirow{2}{*}{$\begin{array}{l}\text { NCBInr } \\
\text { Index code }\end{array}$} & \multirow[t]{2}{*}{ MW } & \multirow[t]{2}{*}{ PI } & \multirow[t]{2}{*}{ Score } & \multicolumn{2}{|c|}{ Spots Intensities } \\
\hline & & & & & & BMEC & CMEC \\
\hline 37 & $\begin{array}{l}\text { guanosine diphosphate (GDP) dissociation } \\
\text { inhibitor } 3\end{array}$ & gi|6679987 & 31229 & 6.75 & 283 & 2786 & 609 \\
\hline 39 & sarcolemma associated protein & gi|6005874 & 52252 & 5.13 & 150 & 3907 & 79 \\
\hline 40 & immune associated nucleotide 1 isoform a & gi|28416440 & 30558 & 5.94 & 327 & 439 & 21 \\
\hline 42 & unknown (protein for IMAGE:5066189) & gi|19353651 & 19028 & 8.90 & 184 & 1764 & 99 \\
\hline 44 & tissue inhibitor of matrix metalloproteinase- 2 & gi|14091321 & 11216 & 6.10 & 151 & 5112 & 69 \\
\hline 45 & vesicle amine transport protein 1 homolog & gi| 23623337 & 52576 & 5.95 & 239 & 6704 & 1230 \\
\hline 46 & PDZ and LIM domain 1 (elfin) & gi|13435939 & 23630 & 6.38 & 215 & 1553 & 108 \\
\hline
\end{tabular}

whereas 7 highly-expressed proteins in CMEC are listed in Table 2. In order to assess the functional relevance of changes in the identified proteins, the proteins were classified into five groups according to their primary functions.

The first group consisted of 5 proteins related with cytokine and growth. Three of them, interleukin-6 (IL-6), epidermal growth factor (EGF) and selenium binding protein 2 (SBP2), were highly expressed in BMEC. Two proteins, namely a tissue inhibitor of matrix metalloproteinase-2 (TIMP-2) and immune-associated nucleotide 1 isoform a (IAN-1), appeared to have a higher level in CMEC. The second group comprised collection of proteins involved in stress with one highlyexpressed in CMEC and two highly-expressed in BMEC. For example, capping protein (actin filament), gelsolinlike (CapG) were found to be expressed mainly in BMEC, whereas PDZ and LIM domain 1 (elfin) was expressed mainly in CMEC. The third group of proteins included a series of metabolic enzymes such as cytosol 
aminopeptidase and others. Another group was involved in signal transduction. Calcium/calmodulin-dependent serine protein kinase membrane-associated guanylate kinase (CASK) in this group had a high level in BMEC. The final group consisted of some hitherto unclassified proteins.

\section{Discussion}

This study compared whole-cell proteins from BMEC and CMEC by a large-scale method of proteomics that involved fractionation of proteins by 2D-PAGE, PDQuest image analysis of CBB-stained gels, and identification of target proteins by MS. Expression of 47 polypeptides was consistently altered in the two cell lines. In addition, we identified 22 protein spots and they had multiple functions and were involved in several metabolic pathways.

Although we found the proteomics-based approach to be valuable in generating novel information, 2D-PAGE bears some of limitations in identifying some membrane proteins and other low-abundance proteins. Due to these limitations, it is not difficult to understand that some well-known characteristic proteins in BMEC such as $\gamma$-glutamyl transpeptidase (GGTP), alkaline phosphatase and glucose transporter (Glut-1) were not readily detected in our analysis.

The current study demonstrated that BMEC and CMEC were different in several aspects including cytokine and growth-related molecules, stress-related proteins, signal transduction proteins, metabolic enzymes and others.

\section{Cytokine and growth-related molecules}

Interleukin-6, highly expressed in BMEC, is a multifunctional cytokine with both protective and destructive actions. Some reports have demonstrated that IL-6 plays positive roles in cerebral ischemia and acts as anti-inflammatory cytokine in endotoxemia and bacterial meningitis by inhibiting leukocyte recruitment in CNS (Loddick et al. 1998, Xing et al. 1998). Further research of the function of IL-6 in brain will help to understand the pathophysiology of brain inflammatory diseases. Other highly expressed proteins in BMEC were EGF and selenium binding protein 2 (SBP2). SBP2 is believed to play a crucial role in the growth inhibitory and anticarcinogenic effects of selenite by acting as growth regulatory proteins (Chu et al. 2004). EGF is a neurotrophic peptide produced in the central nervous system (Peng et al. 1998, Kallmann et al. 2002). High level of EGF may prevent ischemic and free radicalinduced hippocampal damage (Baugnet-Mahieu et al. 1990).

There were two high expression proteins in CMEC in this group: TIMP-2 and IAN-1. Our findings were in accordance with the studies of Harkness et al. (2000) who found that level of TIMP-2 expression in aortic endothelial cell is significantly greater than in CNS-derived endothelia. This may demonstrate functional differences between various vascular endothelia. The functions of IAN-1 are currently not known and may participate in the control of apoptosis (Poirier et al. 1999).

\section{Stress-related proteins}

This study demonstrated that two stress-related proteins, CapG and CLIC4, were highly expressed in BMEC. CapG is a member of the gelsolin/villin family of actin-regulatory proteins. Pellieux et al. (2003) demonstrated that CapG is a good candidate to participant in the differential EC sensitivity to shear stress and is considered to play critical roles against the formation of atherosclerotic plaques. It is well known that atherosclerosis is less extensive in brain vessels than in extracranial vessels while the mechanisms involved remain to be explored. Although atherosclerosis occurs mainly in larger vessels, microvascular endothelial dysfunction is associated with early atherosclerosis and atherosclerosis may also be a microvascular disease (Zeiher et al. 1991, Chen and Henry 1997). Therefore, the present observation that brain endothelium expressed high levels of CapG compared with heart endothelium suggests that brain vessels may be more resistant to atherosclerotic plaques by the anti-shear stress role of CapG. Our study first demonstrated that CLIC4 expressed in endothelial cells, with especially high levels in BMEC. Previous reports have indicated that CLIC4 colocalizes with the tight junction protein $\mathrm{ZO}-1$ in the apical region of polarized epithelial cells, and may play an important role in regulating the blood-brain barrier (BBB) organization (Suh et al. 2004). Other findings concluded that CLIC4 interacts with signaling proteins involved in cell membrane remodeling, and participates in the stress-induced apoptotic response in several cellular compartments (Suginta et al. 2001).

On the contrary, both BMEC and CMEC expressed elfin, but CMEC appeared to have a higher level of this protein. It has been shown that elfin is a 
protein most abundantly expressed in the heart, and is involved in myofibrillogenesis and heart development (Kotaka et al. 2001).

\section{Metabolic enzymes}

In our study, we found a series of metabolic enzymes highly expressed in BMEC, including cytosol aminopeptidase, acetyl-coenzyme A dehydrogenase, long-chain, ornithine aminotransferase, peptidylprolyl isomerase D (cyclophilin D) and 5'-methylthioadenosine phosphorylase. Cyclophilin D has been proved to play pivotal role in the development of ischemic brain damage (Uchino et al. 2003). The presence of cytosol aminopeptidase in BMEC may present an enzymatic barrier to the passage of peptides from the blood into the brain. These highly expressed enzymes meet the high metabolic requirements of the central nervous system tissue (CNS) and maintain the unique characteristics of brain capillaries (Johansson 1990).

\section{Signal transduction proteins}

CASK is $\mathrm{Ca}^{2+}$-dependent signaling protein with structural similarity to tight junction (TJ) proteins in zona occludens-1 (ZO-1)/ZO-2, whereas TJ between brain endothelial cells forms the structural basis of the BBB. Moreover, junctional adhesion molecule (JAM) localized in $\mathrm{TJ}$ is found to the colocalized with CASK at intercellular contacts along the lateral surface of the plasma membrane in human epithelial cells (MartinezEstrada et al. 2001), suggesting that JAM association with CASK is dynamically regulated during junction assembly when CASK in partially released from its cytoskeletal links. We thus propose that the high expression of CASK in BMEC indicates its active participation in BBB formation.

\section{Others}

In this investigation, we encountered some diffe- rentially expressed unclassified proteins. Caldesmon 1 (CaD), VAMP-associated protein of $33 \mathrm{kDa}$ (VAP-33) had a higher level in BMEC. The overexpression of $\mathrm{CaD}$ in capillary endothelial cells inhibits the focal adhesion and leads to a loss of actin stress fibers (Helfman et al. 1999). CaD can also control contractility in endothelial cells and consequently affect adhesion-dependent signaling (Numaguchi et al. 2003). It has been shown that VAP-33 and occlusion are co-localized at the tight junction (Lapierre et al. 1999), suggesting that VAP-33 and occlusion interact. Though the functional implication of an interaction between VAP-33 and occlusion is not clear, VAP-33 may regulate the induction of occlusion at the tight junction. The role of vesicle amine transport protein 1 in CMEC needs to be further determined.

In conclusion, our findings suggest that BMEC and CMEC are associated with a distinct pattern of protein expression. It has appeared from this study that CLIC4, CASK and VAP-33 were widely associated with BMEC, whereas three proteins were found to be colocalized with some tight junction proteins. We speculated that they act as both structural support and a barrier-forming element and that they cooperate with the tight junctions in maintaining the blood-brain barrier. Our data also suggest that BMEC are actively involved in neuroprotection and metabolism. Some of the proteins identified have multiple functions and are involved in several metabolic pathways. Identification and further functional characterization of proteins specifically expressed by these two ECs will have an important impact on our understanding of endothelial functions of different origin.

\section{Acknowledgements}

This study was supported by three National Natural Science Foundations of China (No. 30271509, 39870870, 30300454), Hi-Tech Research and Development Program of China (No. 2002AA2Z346C).

\section{References}

ABBOTT NJ, HUGHES CC, REVEST PA GREENWOOD J: Development and characterisation of a rat brain capillary endothelial culture: towards an in vitro blood-brain barrier. J Cell Sci 103: 23-37, 1992.

BAUGNET-MAHIEU L, LEMAIRE M, BROTCHI J, LEVIVIER M, BORN J, GILLES J, VALKENAERSMICHAUX A, VANGHEEL V: Epidermal growth factor receptors in human tumors of the central nervous system. Anticancer Res 10: 1275-1280, 1990.

BROULAND JP, GILBERT MA, BONNEAU M, PIGNAUD G, BAL DIT SOLIER C, DROUET L: Macro and microheterogeneity in normal endothelial cells: differential composition of luminal glycocalyx and functional implications. Endothelium 6: 251-262, 1999. 
CHI JT, CHANG HY, HARALDSEN G, JAHNSEN FL, TROYANSKAYA OG, CHANG DS, WANG Z, ROCKSON SG, VAN DE RIJN M, BOTSTEIN D: Endothelial cell diversity revealed by global expression profiling. Proc Natl Acad Sci USA 100: 10623-10628, 2003.

CHEN CH, HENRY PD: Atherosclerosis as a microvascular disease: impaired angiogenesis mediated by suppressed basic fibroblast growth factor expression. Proc Assoc Am Physicians 109: 351-361, 1997.

CHILIAN WM. LAYNE SM: Coronary microvascular responses to reductions in perfusion pressure. Evidence for persistent arteriolar vasomotor tone during coronary hypoperfusion. Circ Res 66: 1227-1238, 1990.

CHU R, LIM H, BRUMFIELD L, LIU H, HERRING C, ULINTZ P, REDDY JK, DAVISON M: Protein profiling of mouse livers with peroxisome proliferator-activated receptor alpha activation. Mol Cell Biol 24: 6288-6297, 2004.

GIRARD JP, BAEKKEVOLD ES, YAMANAKA T, HARALDSEN G, BRANDTZAEG P, AMALRIC F: Heterogeneity of endothelial cells: the specialized phenotype of human high endothelial venules characterized by suppression subtractive hybridization. Am J Pathol 155: 2043-2055, 1999.

HARKNESS KA, ADAMSON P, SUSSMAN JD, DAVIES-JONES GA, GREENWOOD J, WOODROOFE MN: Dexamethasone regulation of matrix metalloproteinase expression in CNS vascular endothelium. Brain 123: 698-709, 2000.

HELFMAN DM, LEVY ET, BERTHIER C, SHTUTMAN M, RIVELINE D, GROSHEVA I, LACHISH-ZALAIT A, ELBAUM M, BERSHADSKY AD: Caldesmon inhibits nonmuscle cell contractility and interferes with the formation of focal adhesions. Mol Biol Cell 10: 3097-3112, 1999.

HENDRICKX J, DOGGEN K, WEINBERG EO, VAN TONGELEN P, FRANSEN P, DE KEULENAER GW: Molecular diversity of cardiac endothelial cells in vitro and in vivo. Physiol Genomics 19: 198-206, 2004.

JOHANSSON BB: The physiology of the blood-brain barrier. Adv Exp Med Biol 274: 25-39, 1990.

KALLMANN BA, WAGNER S, HUMMEL V, BUTTMANN M, BAYAS A, TONN JC, RIECKMANN P: Characteristic gene expression profile of primary human cerebral endothelial cells. FASEB J 16: 589-91, 2002.

KOMARU T, KANATSUKA H, SHIRATO K: Coronary microcirculation: physiology and pharmacology. Pharmacol Ther 86: 217-261, 2000.

KOTAKA M, LAU YM, CHEUNG KK, LEE SM, LI HY, CHAN WY, FUNG KP, LEE CY, WAYE MM, TSUI SK: Elfin is expressed during early heart development. J Cell Biochem 83: 463-472, 2001.

LAPIERRE LA, TUMA PL, NAVARRE J, GOLDENRING JR, ANDERSON JM: VAP-33 localizes to both an intracellular vesicle population and with occludin at the tight junction. J Cell Sci 112: 3723-3732, 1999.

LIN AY, RUI YC: Platelet-activating factor induced calcium mobilization and phosphoinositide metabolism in cultured bovine cerebral microvascular endothelial cells. Biochim Biophys Acta 1224: 323-328, 1994.

LODDICK SA, TURNBULL AV, ROTHWELL NJ: Cerebral interleukin-6 is neuroprotective during permanent focal cerebral ischemia in the rat. J Cereb Blood Flow Metab 18: 176-179, 1998.

MARTINEZ-ESTRADA OM, VILLA A, BREVIARIO F, ORSENIGO F, DEJANA E, BAZZONI G: Association of junctional adhesion molecule with calcium/calmodulin-dependent serine protein kinase (CASK/LIN-2) in human epithelial caco-2 cells. J Biol Chem 276: 9291-9296, 2001.

NEUHOFF V, AROLD N, TAUBE D, EHRHARDT W: Improved staining of proteins in polyacrylamide gels including isoelectric focusing gels with clear background at nanogram sensitivity using Coomassie Brilliant Blue G-250 and R-250. Electrophoresis 9: 255-262, 1988.

NISHIDA M, CARLEY WW, GERRITSEN ME, ELLINGSEN O, KELLY RA, SMITH TW: Isolation and characterization of human and rat cardiac microvascular endothelial cells. Am J Physiol 264: H639-H652, 1993.

NUMAGUCHI Y, HUANG S, POLTE TR, EICHLER GS, WANG N, INGBER DE: Caldesmon-dependent switching between capillary endothelial cell growth and apoptosis through modulation of cell shape and contractility. Angiogenesis 6: 55-64, 2003.

PELliEUX C, DESGEORGES A, PIGEON CH, CHAMBAZ C, YIN H, HAYOZ D, SILACCI P: Cap G, a gelsolin family protein modulating protective effects of unidirectional shear stress. J Biol Chem 278: 29136-29144, 2003. 
PENG H, WEN TC, TANAKA J, MAEDA N, MATSUDA S, DESAKI J, SUDO S, ZHANG B, SAKANAKA M. Epidermal growth factor protects neuronal cells in vivo and in vitro against transient forebrain ischemia- and free radical-induced injuries. J Cereb Blood Flow Metab 18: 349-360, 1998.

POIRIER GM, ANDERSON G, HUVAR A, WAGAMAN PC, SHUTTLEWORTH J, JENKINSON E, JACKSON MR, PETERSON PA, ERLANDER MG: Immune-associated nucleotide-1 (IAN-1) is a thymic selection marker and defines a novel gene family conserved in plants. J Immunol 163: 4960-4969, 1999.

RISAU W, ENGELHARDT B, WEKERLE H: Immune function of the blood-brain barrier: incomplete presentation of protein (auto-)antigens by rat brain microvascular endothelium in vitro. J Cell Biol 110: 1757-1766, 1990.

ROSENFELD J, CAPDEVIELLE J, GUILLEMOT JC, FERRARA P: In-gel digestion of proteins for internal sequence analysis after one- or two-dimensional gel electrophoresis. Anal Biochem 203: 173-179, 1992.

SUGINTA W, KAROULIAS N, AITKEN A, ASHLEY RH: Chloride intracellular channel protein CLIC4 (p64H1) binds directly to brain dynamin I in a complex containing actin, tubulin and 14-3-3 isoforms. Biochem J 359: 55-64, 2001.

SUH KS, MUTOH M, NAGASHIMA K, FERNANDEZ-SALAS E, EDWARDS LE, HAYES DD, CRUTCHLEY JM, MARIN KG, DUMONT RA, LEVY JM: The organellular chloride channel protein CLIC4/mtCLIC translocates to the nucleus in response to cellular stress and accelerates apoptosis. J Biol Chem 279: 46324641, 2004.

THUILLEZ C, RICHARD V: Targeting endothelial dysfunction in hypertensive subjects. J Hum Hypertens 19: S21$\mathrm{S} 25,2005$.

UCHINO H, ISHII N, SHIBASAKI F: Calcineurin and cyclophilin D are differential targets of neuroprotection by immunosuppressants CsA and FK506 in ischemic brain damage. Acta Neurochir Suppl 86: 105-111, 2003.

XING Z, GAULDIE J, COX G, BAUMANN H, JORDANA M, LEI XF, ACHONG MK: IL-6 is an antiinflammatory cytokine required for controlling local or systemic acute inflammatory responses. J Clin Invest 101: 311-320, 1998.

ZEIHER AM, DREXLER H, WOLLSCHLAGER H, JUST H: Endothelial dysfunction of the coronary microvasculature is associated with coronary blood flow regulation in patients with early atherosclerosis. Circulation 84: 1984-1992, 1991.

\section{Corresponding author}

Yao-Cheng Rui, Department of Pharmacology, School of Pharmacy, Second Military Medical University, 325 GuoHe Road, Shanghai 200433, China. Fax: 86-21-25074471.E-mail: ruiyc2005@yahoo.com 